\title{
Intake, Digestibility, Body Weight and Carcass Characteristics of Tigray Sheep Fed Tef Straw Supplemented with Sesame Seed Meal or Wheat Bran and their Mixtures
}

\author{
Zemicael Gebreslassie ${ }^{1}$ and Solomon Melaku ${ }^{2 *}$ \\ ${ }^{1}$ Enda Selassie ATVET College, P O Box 07, Shire, Tigray, Ethiopia \\ 2Department of Animal Science, Haramaya University, P O Box 138, Dire Dawa, Ethiopia
}

\begin{abstract}
The study was conducted over 90 days feeding and 7 days digestibility trials at Enda Selassie ATVET College to assess the effect of supplementation on feed utilization and carcass characteristics in tef (Eragrostis tef) straw based feeding of Tigray rams. The rams were arranged in a randomized complete block design divided into five blocks based on initial BW. The treatments comprised of ad libitum tef straw (control, T1) and daily supplementation with $300 \mathrm{~g}$ dry matter (DM) sole sesame (Sesame indicum) seed meal (SSM, T2), 0.65SSM:0.35 wheat bran (WB, T3), 0.35SSM:0.65WB (T4) and sole WB (T5). Tef straw used in the study contained low $\left(30.6 \mathrm{~g} \mathrm{~kg}^{-1} \mathrm{DM}\right)$ crude protein (CP) and high $\left(825.8 \mathrm{~g} \mathrm{~kg}^{-1} \mathrm{DM}\right)$ neutral detergent fiber (NDF) contrary to the supplement feeds. Total daily $\mathrm{DM}$ intake and DM intake as a percentage of BW were higher $(\mathrm{P}<0.001)$ for the supplemented rams (701.4-725 $\mathrm{g} \mathrm{day}^{-1}$ and 2.57-2.63\%) than those fed solely on tef straw (403.1 $\mathrm{g} \mathrm{day}^{-1}$ and $1.8 \%$ ). The $\mathrm{CP}$ intake increased $(\mathrm{P}<0.001)$ in the order $\mathrm{T} 2>\mathrm{T} 3>\mathrm{T} 4>\mathrm{T} 5>\mathrm{T} 1$. Daily $\mathrm{BW}$ gain was negative and lower $(\mathrm{P}<0.001)$ in rams fed solely on tef straw $\left(-22 \mathrm{~g} \mathrm{~g} \mathrm{day}^{-1}\right)$ compared to the supplemented ones $\left(50-71.1 \mathrm{~g} \mathrm{day}^{-1}\right)$. Out of all supplemented treatments, T5 was lower $(\mathrm{P}<0.001)$ in apparent digestibility of CP and daily BW gain compared to T2, T3 and T4. Hot carcass weight and empty BW were higher $(\mathrm{P}<0.001)$ for T2, T3, T4 compared to T1. Dressing percent on slaughter weight base was higher $(\mathrm{P}<0.001)$ for supplemented $(39.5-43.4 \%)$ compared to the control treatment $(32.9 \%)$. Out of all supplements, SSM and its mixtures with WB resulted in better performance of the sheep compared to supplementation with sole WB.
\end{abstract}

Keywords: Tigray Sheep; Body Weight; Carcass; Intake; Sesame Seed Meal; Tef Straw; Wheat Bran

\section{Introduction}

Small ruminants are valuable sources of meat, milk and fiber globally. The economic importance of small ruminants is far-reaching in countries with developing economies such as Ethiopia since they are immediate sources of cash income, serve as a saving account, ensure household food security, and are used as a means to build assets and alleviate poverty among the poorest sections of society. Moreover, meat from small ruminants is ideal for family consumption without deteriorating in quality owing to their comparatively small carcass size, particularly in rural communities which lack effective cooling systems for meat preservation (Devendra, 2001).

Although Ethiopia has a large population of sheep that are widely distributed across all agro-ecological zones of the country, their productivity is very low, mainly due to inadequate production inputs such as animal feeds. Most of the sheep in Ethiopia which are owned by smallholder farmers and pastoralists depend entirely on natural grasslands and crop aftermaths as sources of feeds. These feed resources contain less than $7 \%$ crude protein (CP) and more than $75 \%$ neutral detergent fiber (NDF) (Seyoum and Zinash, 1995), which compromise feed intake and digestibility, resulting in inadequate nutrient supply to satisfy the maintenance requirement of sheep, and thus cause severe weight losses, particularly in the non-forage growing season.

Therefore, it is imperative to improve the utilization of poor quality feed resources such as crop residues by correcting their nutrient deficiencies. One alternative in this regard is the use of agro-industrial by-products as supplements in straw-based feeding of livestock (Reverdin and Sauvant, 1991). Such a strategy could enable the high nutrient requirements for growing livestock to be met in order to attain desired degree of finish for the market. Out of all the agro-industrial byproducts available in Ethiopia, sesame seed meal (SSM) and wheat bran (WB) could be used as feed supplements in crop residue based feeding of sheep.

However, these by-products are not effectively utilized by smallholder farmers in their area of production, mainly due to lack of information about their potential as feed supplements as well as the optimum ratio at which they can be mixed in supplementary rations for sheep. Therefore, this experiment was conducted with the objective of studying the effect of supplementing SSM, WB and their mixtures at 0.65 SSM:0.35WB and 0.35SSM:0.65WB on feed intake, digestibility, body weight (BW) change and carcass parameters in tef (Eragrostis tef) straw based feeding of Tigray rams.

\section{Materials and Methods}

2.1. Description of the Study Area

The experiment was conducted at Enda Selassie Agricultural Technical Vocational, Education and Training (ATVET) College located at $14^{\circ} 06^{\prime} \mathrm{N}, 38^{\circ} 17^{\prime} \mathrm{E}$ and at an altitude of 1860 masl in the Northwestern Zone of Tigray Regional State, Ethiopia. The mean annual rainfall is $700-900 \mathrm{~mm}$, mean annual minimum and maximum temperature is $10^{\circ} \mathrm{C}$ and $27{ }^{\circ} \mathrm{C}$, respectively (Zemichael, 2007).

\subsection{Animals, Experimental Design and Treatments}

Twenty-five yearling Tigray rams with mean initial BW of $23.1 \pm 0.81 \mathrm{~kg}$ (mean $\pm \mathrm{SD})$ were used in the experiment that lasted for 90 days of feeding and 7 days of digestibility trials. The animals were quarantined for three weeks during which time they were dewormed and 
sprayed against internal and external parasites, respectively, as well as vaccinated against pasteurellosis. The rams were blocked based on initial BW into five blocks of five animals in a randomized complete block design. The five dietary treatments (Table 1) were randomly assigned to each animal in a block giving five animals per treatment.

Table 1. Experimental treatments.

\begin{tabular}{llll}
\hline Treatment & Tef straw & Supplement & Quantity \\
\hline Treatment 1(control) & Ad libitum & 0 & \\
Treatment 2 & Ad libitum & SSM & $300 \mathrm{~g} \mathrm{DM} \mathrm{day}^{-1}$ \\
Treatment 3 & Ad libitum & $0.65 S S M: 0.35 \mathrm{WB}$ & $300 \mathrm{~g} \mathrm{DM} \mathrm{day}^{-1}$ \\
Treatment 4 & Ad libitum & $0.35 S S M: 0.65 \mathrm{WB}$ & $300 \mathrm{~g} \mathrm{DM} \mathrm{day}^{-1}$ \\
Treatment 5 & Ad libitum & WB & $300 \mathrm{~g} \mathrm{DM} \mathrm{day}^{-1}$ \\
\hline
\end{tabular}

$\overline{D M}=d r y$ matter; $S S M=$ sesame seed meal; $W B=$ wheat bran;

\subsection{Feeds and Feeding Management}

Tef straw, common salt block and water were offered ad libitum. The supplement feeds, consisting of sole SSM, sole WB or mixtures of both at $0.65 \mathrm{SSM}: 0.35 \mathrm{WB}$ and $0.35 \mathrm{SSM}: 0.65 \mathrm{WB}$ were offered at the rate of $300 \mathrm{~g} \mathrm{DM} /$ day in two equal portions at 08:00 $\mathrm{h}$ and 16:00 $\mathrm{h}$ daily. The SSM and WB were thoroughly mixed at the given proportions after grinding the sesame seed cake into a meal. The tef straw and the supplement feeds were offered in separate troughs per experimental sheep. Daily supplement and basal feed offers and refusals were weighed and recorded for each sheep to calculate daily feed intake. Samples of feed offer were taken per batch of feed and refusals were collected per animal over the experimental period, pooled on treatment basis and subsampled for laboratory analysis.

\subsection{Digestibility Trial}

The digestibility trial was conducted at the end of the feeding trial using a completely randomized design. Four sheep from each treatment were adapted to the carrying of fecal bags for three days. This was followed by total collection of feces for seven days per animal. Feces collected in the fecal bags over 24 hours were weighed every morning for each sheep. Twenty percent of the voided feces were sampled and pooled for each animal over the collection period. The fecal samples were stored at $-20{ }^{\circ} \mathrm{C}$. At the end of the feces collection, the fecal samples were dried in a forced air oven at $55{ }^{\circ} \mathrm{C}$ for 48 hours and ground to pass through a $1 \mathrm{~mm}$ sieve. The ground samples were stored in airtight plastic containers until required for analysis. The sheep were weighed at the beginning and the end of the digestibility trial. The digestibility coefficient of nutrients was determined as the proportion of nutrients consumed but not recovered in feces.

\subsection{Body Weight and Carcass Parameters}

Body weight of each animal was measured at the beginning of the experiment and every 10 days after overnight fasting to account for the confounding effect of gut fill on BW. Daily BW gain was calculated as the difference between the final and initial BW divided by the number of feeding days. The feed conversion ratio (FCR) was calculated as a proportion of daily DM intake to the daily BW gain. At the end of the feeding and digestibility trial, twenty sheep, four from each treatment were slaughtered after overnight fasting. Blood, skin with legs below the fetlock joints, head (with horn, tongue, and ear), reproductive organs (testis and penis), organs in the peritoneal sac (lung, heart and trachea) and organs in the abdominal sac (empty gut, liver, gall bladder, kidney, spleen and pancreas, kidney), omental and channel fat as well as hot carcass weights were weighed. Dressing percent was calculated as a proportion of carcass weight to slaughter weight or empty BW. The cross section of the rib-eye muscle was traced on transparent plastic foil between the $11^{\text {th }}$ and $12^{\text {th }}$ ribs on both sides. The traced rib eye muscle area was placed on a square paper which had a grid area of $1 \times 1 \mathrm{~mm}$ and the numbers of squares within the traced grid were counted to calculate the rib eye muscle area. Squares with more than $50 \%$ of their area in the grid were accounted for as full squares, whereas those with less than $50 \%$ of their area in the grid were not counted. Half squares in the traced area were accounted for their actual size.

\subsection{Chemical Composition}

Ash, DM and $\mathrm{CP}$ were determined according to AOAC (1990). The NDF, acid detergent fiber (ADF) and acid detergent lignin (ADL) were analyzed according to Van Soest and Robertson (1985).

\subsection{Statistical Analysis}

The experimental data were subjected to the analyses of variance using the general linear model procedure of SAS (1998). Treatment means were separated by least significant difference test. The statistical model used for analyzing data on feed intake and BW was:

$$
Y_{i j}=\mu+T_{i}+B_{j}+E_{i j} \text { where, }
$$

$\mathrm{Y}_{\mathrm{ij}}=$ the response variable; $\mu=$ the overall mean; $\mathrm{T}_{\mathrm{i}}=$ the treatment effect; $\mathrm{B}_{\mathrm{i}}=$ the block effect; $\mathrm{E}_{\mathrm{ij}}=$ the random error.

Data collected on digestibility and carcass parameters were analyzed using the model;

$$
\mathrm{Y}_{\mathrm{ij}}=\mu+\mathrm{T}_{\mathrm{i}}+\mathrm{E}_{\mathrm{ij}} \text { where, }
$$

$Y_{i j}=$ the response variable; $\mu=$ the overall mean; $T_{i}=$ the treatment effect; $E_{i j}=$ the random error.

\section{Results and Discussion}

\subsection{Chemical Composition of Treatment Feeds}

The CP content of SSM in this study (Table 2) was higher than the CP content of 30.93\% (Solomon, 1992) and 38\% (Enseminger, 2002). The differences in the composition of SSM used in this study and that reported in the other studies may be due to the differences in the methods and efficiencies of extracting oil from the sesame seed as well as differences in the varieties of sesame seed (Solomon, 1992; Enseminger, 2002). The CP NDF, ADF, ADL contents of WB used in this study were comparable to the results reported by Solomon et al., 2004. Tef straw contained low $\mathrm{CP}$, but high NDF and ADF fractions, contrary to the content of the constituents in the supplement feeds which justify the use of the 
supplements in tef straw-based feeding of sheep.

Table 2. The chemical compositions of treatment feeds.

\begin{tabular}{llllll}
\hline Composition & Tef straw & SSM & $0.65 S S M: 0.35 W B$ & $0.35 S S M: 0.65 W B$ & WB \\
\hline DM $\left(\mathrm{g} \mathrm{kg}^{-1}\right)$ & 881.4 & 812.4 & 829.5 & 844.1 & 861.2 \\
OM $\left(\mathrm{g} \mathrm{kg}^{-1} \mathrm{DM}\right)$ & 947.5 & 941.8 & 946.5 & 950.5 & 955.2 \\
$\mathrm{CP}\left(\mathrm{g} \mathrm{kg}^{-1} \mathrm{DM}\right)$ & 30.6 & 437.5 & 342.7 & 261.4 & 166.6 \\
$\mathrm{NDF}\left(\mathrm{g} \mathrm{kg}^{-1} \mathrm{DM}\right)$ & 825.8 & 183.7 & 283.1 & 368.4 & 467.8 \\
$\mathrm{ADF}\left(\mathrm{g} \mathrm{kg}^{-1} \mathrm{DM}\right)$ & 491.7 & 103.4 & 113.0 & 121.2 & 130.8 \\
ADL $\left(\mathrm{g} \mathrm{kg}^{-1} \mathrm{DM}\right)$ & 53.2 & 15.0 & 21.4 & 26.9 & 33.3 \\
Hemicellulose $\left(\mathrm{g} \mathrm{kg}{ }^{-1} \mathrm{DM}\right)$ & 334.1 & 80.3 & 170.1 & 247.2 & 337.0 \\
Cellulose $\left(\mathrm{g} \mathrm{kg}^{-1} \mathrm{DM}\right)$ & 438.5 & 88.4 & 91.6 & 94.3 & 97.5
\end{tabular}

$A D F=$ acid detergent fiber; $A D L=$ acid detergent lignin; $D M=$ dry matter; $C P=$ crude protein; $N D F=$ neutral detergent fiber; $O M=$ organic matter; $S S M=$ sesame seed meal; $W B=$ wheat bran.

\subsection{Feed Intake}

Supplementation did not affect $(\mathrm{P}>0.05)$ tef straw DMI (Table 3), although Preston and Leng (1984) suggested that supplements can substitute fibrous feeds if the levels of supplementation exceed $20 \%$ of total DM intake. This result agrees with that of Nsahlai et al. (1999), where supplementation of sheep fed tef straw basal feed with oilseed cake and tanniferous feeds (pods of Acacia albida and Sesbania sesban leaves) had no effect on the intake of tef straw. Supplemented sheep had higher $(\mathrm{P}<0.001)$ total DM intake than unsupplemented ones, which is similar to the results of other studies (Swanson et al., 2000; Kabir et al., 2004). The increase in total DM intake in the supplemented sheep might be due to better contents of $\mathrm{CP}$ in the supplement feeds. This provided adequate CP for the rumen micro-organisms to speed up fermentation of feed which, in turn, might have reduced feed retention time in the rumen, leading to more total DM intake. Moreover, supplementation might have improved the supply of escape protein at tissue level which covered amino acids in which microbial protein was deficient, thus improving the balance of absorbed nutrients which, consequently, could have promoted total DM intake. Indeed, Swanson et al. (2000) suggested that the supply of amino acids at tissue level improved DM intake. In contrast to the above result, Shahjalal et al. (2000) reported similar DM intake in goats supplemented with high protein and energy sources and those maintained otherwise. Kabir et al. (2004) also showed similarity in DM intake in grazing goats supplemented with high protein or low protein diets. The higher $(\mathrm{P}<0.001) \mathrm{CP}$ intake observed in supplemented treatments compared to the control was expected, since the tef straw was deficient in CP content. Out of all supplemented sheep, the difference $(\mathrm{P}<0.001)$ in $\mathrm{CP}$ intake was in the order of $\mathrm{T} 2$ $>\mathrm{T} 3>\mathrm{T} 4>\mathrm{T} 5$, and this could be attributed to the differences in CP content of the treatment diets, which is a reflection of higher $\mathrm{CP}$ content in sole SSM or in its mixture with WB.

\subsection{Apparent Digestibility}

The apparent digestibility of $\mathrm{CP}$ was higher $(\mathrm{P}<0.001)$ for the supplemented compared to the nonsupplemented sheep (Table 4) which is indeed a function of the higher CP supplied by the supplements. Ash and Norton (1987) also showed that supplementation with protein rich diets in goats significantly improved nitrogen digestibility compared to low protein diets. Among the supplemented sheep, SSM resulted in higher $(\mathrm{P}<0.001)$ apparent digestibility of $\mathrm{CP}$ than WB. The difference in digestibility of CP between SSM and WB fed sheep in this study may be due to the low content of CP and higher proportion of cell wall fiber in WB which might have reduced the apparent digestibility of $\mathrm{CP}$ in the latter.

Table 3. Daily feed intake of Tigray sheep fed tef straw supplemented with sesame seed cake, wheat bran and their mixtures at different proportions.

\begin{tabular}{|c|c|c|c|c|c|c|c|}
\hline Feed intake & T1 & $\mathrm{T} 2$ & T3 & T4 & T5 & SL & SEM \\
\hline Tef straw DMI $\left(\mathrm{g} \mathrm{d}^{-1}\right)$ & 403.1 & 423.0 & 413.5 & 415.6 & 401.3 & ns & 14.4 \\
\hline Supplement DMI $\left(\mathrm{g} \mathrm{d}^{-1}\right)$ & - & 300.0 & 300.0 & 300.0 & 300.0 & ns & 0.00 \\
\hline Total DMI $\left(\mathrm{g} \mathrm{d}^{-1}\right)$ & $403.1^{\mathrm{b}}$ & $723.0^{\mathrm{a}}$ & $713.5^{\mathrm{a}}$ & $715.6^{\mathrm{a}}$ & $701.4^{\mathrm{a}}$ & $* * *$ & 14.4 \\
\hline Tef straw DMI (\% BW) & 1.80 & 1.53 & 1.48 & 1.49 & 1.50 & ns & 0.08 \\
\hline Supplement DMI (\% BW) & - & 1.09 & 1.08 & 1.08 & 1.13 & ns & 0.03 \\
\hline Total DMI (\% BW) & $1.80^{\mathrm{b}}$ & $2.62^{\mathrm{a}}$ & $2.61^{\mathrm{a}}$ & $2.57^{\mathrm{a}}$ & $2.63^{\mathrm{a}}$ & $* * *$ & 0.09 \\
\hline Substitution rate & - & 0.09 & 0.12 & 0.12 & 0.12 & ns & 0.27 \\
\hline Total CP intake $\left(\mathrm{g} \mathrm{d}^{-1}\right)$ & $12.3^{e}$ & $144.2^{\mathrm{a}}$ & $115.5^{b}$ & $91.14^{c}$ & $62.3^{\mathrm{d}}$ & $* * *$ & 0.44 \\
\hline Total NDF intake $\left(\mathrm{g} \mathrm{d}^{-1}\right)$ & $332.9^{c}$ & $404.5^{b}$ & $437.5^{\mathrm{ab}}$ & $453.7 \mathrm{ab}$ & $471.8^{\mathrm{a}}$ & $* * *$ & 11.9 \\
\hline Total ADF intake $\left(\mathrm{g} \mathrm{d}^{-1}\right)$ & $198.2^{\mathrm{b}}$ & $239^{a}$ & $243.8^{\mathrm{a}}$ & $240.7^{a}$ & $236^{\mathrm{ab}}$ & $* *$ & 7.06 \\
\hline
\end{tabular}


Table 4. Apparent digestibility of nutrient in Tigray sheep fed tef straw supplemented with sesame seed cake, wheat bran and their mixtures at different proportions.

\begin{tabular}{|c|c|c|c|c|c|}
\hline \multirow[t]{2}{*}{ Treatments } & \multicolumn{5}{|c|}{ Digestibility coefficient } \\
\hline & $\overline{\mathrm{DM}}$ & OM & $\mathrm{CP}$ & NDF & ADF \\
\hline T1 & 0.52 & 0.58 & $-0.12^{c}$ & 0.57 & 0.63 \\
\hline $\mathrm{T} 2$ & 0.61 & 0.63 & $0.81^{\mathrm{a}}$ & 0.50 & 0.55 \\
\hline T3 & 0.55 & 0.59 & $0.74^{\mathrm{ab}}$ & 0.44 & 0.51 \\
\hline T4 & 0.61 & 0.65 & $0.72^{\mathrm{ab}}$ & 0.53 & 0.59 \\
\hline T5 & 0.59 & 0.63 & $0.60^{\mathrm{b}}$ & 0.50 & 0.56 \\
\hline SL & ns & ns & $* * *$ & ns & ns \\
\hline SEM & .023 & .024 & .026 & .077 & .022 \\
\hline
\end{tabular}

\subsection{Body Weight and Carcass Parameters}

The supplemented sheep excelled $(\mathrm{P}<0.001)$ compared to the non- supplemented ones in final BW, BW change during the experimental period, and daily BW gain (Table 5), which was in agreement with other studies (Bonsi et al., 1994; Nsahlai et al., 1999; Solomon et al., 2004) which reported increased BW gain in small ruminants as a result of supplementation with high energy or protein sources or both in an attempt to bridge the gap between dry and wet season feed availability or for fattening purposes. The BW change and daily $\mathrm{BW}$ gain were higher $(\mathrm{P}<0.001)$ for sheep supplemented with SSM compared to those supplemented with WB and this could be attributed to higher intake and better apparent digestibility of $\mathrm{CP}$ in the former. This was indeed in agreement with Owens and Zinn (1988) who, after reviewing a large body of data, reported that added dietary protein resulted in increased rate of BW gain in over $85 \%$ of the feeding trials due due to meeting the energy and protein requirements of the animals for tissue accretion.

The sheep on the control diet continuously lost BW. Similar results were recorded by Abule (1994) in calves fed sole tef straw, which lost BW at the rate of $-75.76 \mathrm{~g} \mathrm{~d}^{-}$ 1. Loss of BW at the rate of $-17.5 \mathrm{~g} \mathrm{~d}^{-1}$ (Kaitho, 1997) and $-24.4 \mathrm{~g} \mathrm{~d}^{-1}$ (Kaitho, 1998) was also reported for sheep fed solely on tef straw. This could be due to the high cell wall fiber content in tef straw resulting in low rumen fermentation, digestibility and voluntary feed intake, thereby limiting BW gain in the sheep. The Higher level of daily BW loss in the current study compared with the aforementioned studies could be attributed to the poor nutrient content of the tef straw used in this study. Sheep supplemented with sole WB had lower $(\mathrm{P}<0.001)$ daily $\mathrm{BW}$ gain compared to sheep supplemented with sole SSM or the higher proportion of SSM with WB, indicating that sole or higher proportion of SSM in the supplement was more effective in promoting daily BW gain due to better chemical composition. Similar results were reported by Getnet (1998) in which kids from lactating does supplemented with a higher proportion of groundnut cake in a mixture with wheat bran had a higher BW gain. Lema (1993) compared supplementation with leguminous hay and oil seed cakes to growing sheep fed tef straw as a basal diet and concluded that different sources of CP even at equal intakes may result in different BW gains. Similarly, supplementation with mixtures of multi- purpose trees resulted in higher BW gain and final BW compared to supplementation with wheat bran or sole multi-purpose trees (Solomon et al., 2004). This could be attributed to the nature of the protein sources, where protein sources which are slowly degradable in the rumen resulted in the better BW gain. Indeed, Solomon (1992) indicated that mechanically pressed SSM had intermediate rumen degradability and high energy content. Therefore, the higher daily BW gain observed in this study in sheep supplemented with a high proportion of SSM or with sole SSM compared to sole WB- supplemented sheep could be attributed to the intermediate rumen degradability of SSM (Solomon, 1992) allowing more absorption of escape protein at intestinal level as well as also supplying adequate rumen degradable protein to the rumen microbes. The lack of differences between sheep supplemented solely with SSM or its higher mixture with WB in daily BW gain might be attributed to the similar quality of protein available in the small intestine, even accounting for differences in CP intake between sheep in both treatments. The hypothesis for explaining the observed similarity in BW gain could be that a higher proportion of the dietary protein in sheep fed on the highest CP intake might have been wasted by degradation in the rumen resulting in excess ammonia than could be utilized by the rumen microorganisms. Excess CP beyond the requirements of rumen microbes is either recycled or excreted in urine (McDonald et al., 2002) and the latter may be the reason for obtaining the observed similar BW gain in both treatments. Thus, the feed offer should account for the quantity of CP which is effectively utilized by sheep. Comparable BW gains to the results of this study were reported by Shahjalal (2000). The low BW gain in sheep supplemented with sole $\mathrm{WB}$ may be due to lower $\mathrm{CP}$ and high NDF, ADF and ADL content in WB that could have reduced nutrient utilization in experimental sheep in this treatment. Similar results were reported by Getnet (1998) and Solomon et al. (2004).

Feed conversion ratio was lower $(\mathrm{P}<0.001)$ for the supplemented compared to the non-supplemented sheep. Feed conversion ratio increased with a decrease in the proportion of SSM, indicating that the sheep used SSM with better efficiency for BW gain. The higher feed conversion ratio for WB supplemented and tef straw consuming sheep compared to SSM supplemented sheep in this experiment might be due to the result of low 
energy and CP intake, type of CP and the high fiber content of the former diets which resulted in reduced digestibility of nutrients and efficiency of utilization of metaboliziable energy. Supplemented sheep had higher dressing percent $(\mathrm{P}<0.001)$ on slaughter weight basis than the non-supplemented ones (Table 5). In this study, the observed dressing percent on slaughter weight base ranged between $32.9-43.4 \%$, and this result was comparable to the report of Beniam et al. (1983) for Somali and Afar sheep (36-43.8\%) as well as with the dressing percent reported by Devendra and Burns (1983) which ranged between $35-60 \%$. A relatively higher dressing percent compared to in the present study was reported by Galal et al. (1979) for Ethiopian Highland sheep $(41.2 \%)$ and Horro lambs $(47.7 \%)$. The rib eye muscle area was higher $(\mathrm{P}<0.05)$ for sole SSM supplemented sheep compared to those offered only tef straw. Comparable results were reported by Galal and Kasahun (1981) for Afar sheep in Ethiopia.

Table 5. Body weight and carcass parameters of Tigray sheep fed tef straw supplemented with sesame seed cake, wheat bran and their mixtures at different proportions.

\begin{tabular}{|c|c|c|c|c|c|c|c|}
\hline Parameters & T1 & $\mathrm{T} 2$ & T3 & $\mathrm{T} 4$ & T5 & SL & SEM \\
\hline Initial BW (kg) & 23.2 & 23.2 & 23.3 & 23.1 & 22.7 & ns & 0.42 \\
\hline Final BW (kg) & $21.2^{\mathrm{b}}$ & $29.6^{a}$ & $29.5^{\mathrm{a}}$ & $29.0^{\mathrm{a}}$ & $27.2^{\mathrm{a}}$ & $* * *$ & 0.49 \\
\hline BW change $(\mathrm{kg})$ & $-1.98 c$ & $6.4^{\mathrm{a}}$ & $6.38^{a}$ & $5.94 \mathrm{ab}$ & $4.5^{\mathrm{b}}$ & $* * *$ & 0.27 \\
\hline Daily BW gain (g) & $-22.0^{c}$ & $71.1^{\mathrm{a}}$ & $70.9^{a}$ & $66.0^{\mathrm{ab}}$ & $50.0^{\mathrm{b}}$ & $* * *$ & 2.99 \\
\hline FCR & $-19.1^{b}$ & $10.3^{\mathrm{a}}$ & $10.2^{\mathrm{a}}$ & $10.8^{a}$ & $14.2^{\mathrm{a}}$ & $* * *$ & 1.06 \\
\hline Hot carcass weight $(\mathrm{kg})$ & $6.9^{\mathrm{b}}$ & $12.1^{\mathrm{a}}$ & $11.8^{\mathrm{a}}$ & $12.3^{\mathrm{a}}$ & $10.8^{\mathrm{ab}}$ & $* * *$ & 0.7 \\
\hline Empty BW (kg) & $14.6^{\mathrm{b}}$ & $24.1^{\mathrm{a}}$ & $22.6^{\mathrm{a}}$ & $23.3^{\mathrm{a}}$ & $19.1^{\mathrm{ab}}$ & $* *$ & 1.27 \\
\hline Dressing percent $(\% \mathrm{SW})$ & $32.9^{\mathrm{b}}$ & $41.5^{\mathrm{a}}$ & $41.9^{a}$ & $43.4^{\mathrm{a}}$ & $39.5^{\mathrm{a}}$ & $* * *$ & 0.83 \\
\hline Dressing percent (\% EBW) & $47.2^{\mathrm{b}}$ & $50.2^{\mathrm{ab}}$ & $52.2^{\mathrm{ab}}$ & $53.1^{\mathrm{a}}$ & $51.2^{\mathrm{ab}}$ & $*$ & 1.33 \\
\hline Rib - eye muscle area & $7.5^{\mathrm{b}}$ & $12.7^{\mathrm{a}}$ & $11.5^{\mathrm{ab}}$ & $11.7^{\mathrm{ab}}$ & $11.0^{\mathrm{ab}}$ & $*$ & 1.1 \\
\hline
\end{tabular}

\section{Conclusions}

Supplementation with SSM, WB and their mixtures maintained tef straw intake and improved total DM intake which, subsequently, resulted in better BW gain and final BW. The results showed that supplementation with sole SSM or its mixture with WB (0.65SSM: $0.35 \mathrm{WB})$ required less feed for a unit of BW gain compared to supplementation solely with WB.

\section{References}

Abule, E. 1994. Performance of crossbred calves fed on tef (Eragrostis tef) straw supplemented with graded levels of cowpea (Vigna unguiculata) and Dolochos lablab (Lablab perpureus) hay. MSc Thesis. Alemaya University of Agriculture, Alemaya, Ethiopia.

AOAC (Association of Official Analytical Chemists). 1990. Official Methods of Analysis. Association of Offici al Analytical Chemists, Washington, D.C. pp. 1298.

Ash, A.J. and Norton, W.B. 1987. Studies with Australian Cashmere goats. II. Growth and digestion in male and female goats given pelleted diets varying in protein content and energy level. Australian Journal of Agricultural Research 38: 957-969.

Beniam, A., Galal, E.S.E., Demissie, T. and Gebresadikan H. 1983. A summary of carcass measurements on some Ethiopian sheep and goats. Institution of
Agricultural Research, Addis Ababa. Ethiopia. Animal Production Bulletin. pp.15.

Bonsi, M.L.K., Osuji, P.O., Nsahlai, I.V. and Tuah, A.K. 1994. Graded levels of Sesbania sesban, and Leucaena leucocephala as supplement to tef straw given to Ethiopian Menz sheep. Animal Production 59: 235-244.

Devendra, C. and Burns, M. 1983. Goat Production in the Tropics. $2^{\text {nd }}$ edition. Commonwealth Agricultural Bureax, UK.

Devendra, C. 2001. Small ruminants: imperatives for productivity enhancement, improved livelihoods and rural growth - review. Asian Australian Journal of Animal Science 14:1481-1496.

Enseminger, M.E. 2002. Sheep and Goat Science. International Publishers, Inc., Danville, Illinois.

Galal, E.S.E., Kassahun, A., Beyene, K., Yohannes, G., and O’Donovan, P.B. 1979. A study of fattening Ethiopian sheep: 1. Performance of high land lambs under feedlot conditions. Ethiopian Journal of Agricultural Science 1: 93-98.

Galal, E.S.E. and Kasahun, A. 1981. Ethiopian Adal sheep: genetic and environment factors affecting body weight and post-weaning gain. International Goat and Sheep Research 1: 310-318.

Getnet, B. 1998. Performance of Somali goats supplemented with different proportion of 
groundnut cake and wheat bran. MSc Thesis, Alemaya University of Agriculture, Ethiopia.

Kabir, F., Sultana, M.S., Shahjalal, M., Khan, J.M. and Alem, Z.M. 2004. Effect of protein supplementation on growth performance in female goats and sheep under grazing condition. Pakistan Journal of Nutrition 3: $23-239$.

Kaitho, R.J., Umunna, N.N., Nsahlai, I.V., Tamminga, S., and Van Bruchem, J. 1998. Effecet of feeding graded level of Lucaena lucocephala, Lucaena pallida, Sesbania sesban, Chamaeytisus palmensis supplements to tef straw given to Ethiopian highland sheep. Animal Feed Science and Technology 72: 355-366.

Kaitho, R.J. 1997. Nutritive value of browses as protein supplement to poor quality roughages. $\mathrm{PhD}$ Thesis, Wageningen Agricultural University, The Netherlands.

Lema, G. 1993. Comparison of legume hay, urea and noug cake as protein supplement for sheep fed tef straw. In: Proceedings of the Fourth National Livestock Improvement Conference. 13-15 November 1991; Addis Ababa, Ethiopia. pp. 211215.

McDonald, P., Edwards, R.A., Greenhalgh, J.F.D. and Morgan, C.A. 2002. Animal Nutrition. 6 ${ }^{\text {th }}$ edition. Prentice- Hall, Inc., London, UK.

Nsahlai, I.V., Umunna, N.N., Osuji, P.O. 1999. Influence of feeding sheep on oil cake following the consumption of tanniferous feeds. Livestock Production Science 60: 59-69.

Owens, F.N., Zinn, R. 1988. Protein metabolism of ruminant animals. In: Church, D.C. (eds.). The Ruminant Animal Digestive Physiology and Nutrition. Waveland Press Inc., Prospect Hights, IL, USA, pp. 227-249.

Preston, T.R. and Leng, R.A. 1984. Supplementation of diets based on fibrous residues and by-products. In: Sundstol, F. and Owens, E. (eds.). Straw and Other Fibrous By-products as Feeds. Elsevier Publishing Company. The Netherlands. pp. 373-413.

Reverdin, S.G., and Sauvant, D. 1991. Evaluation and utilization of concentrates in goats. In: Morand-Fehr,
P. (eds.). Goat Nutrition. EAAP Publication No 46, Pudoc, Wageningen, The Netherlands. pp. 172-183.

SAS (Statistical Analysis System Institute). 1998. SAS/STAT Guide to Personal Computers, Version 7. Statistical Analysis System Institute. Inc., NC. North Carolina, USA.

Seyoum, B. and Zinash, S. 1995. Chemical composition, in vitro digestibility and energy value of Ethiopian feedstuffs. In: Proceeding of the Third National Conference of the Ethiopian Society of Animal Production, Addis Ababa, Ethiopia held 27-29 April 1995, Addis Ababa, Ethiopia. pp.307-311.

Shahjalal, M., Bishwas, A.M., Tareque, A. and Hoki, M.M. 2000. Growth and carcass cheractersticies of goats given diets variying protein concentration and feeding level. Asian-Australian Journal of Animal Science 13: 613-618.

Solomon, M., Peters, K.J. and Azage,T. 2004. Effect of supplementation with foliage of selected multipurpose trees and their mixtures or wheat bran on feed intake, plasma enzyme activities, live weight and scrotal circumference gains in Menz sheep. Livestock Production Science 253-264.

Solomon, M. 1992. The effect of processing methods of oil seed cakes in Ethiopia on their nutritive value: In vitro $\mathrm{N}$-degradability and $\mathrm{N}$-metabolism in growing sheep fed a basal diet of maize stover. PhD. Thesis, University of Bonn, Germany.

Swanson, E.W. 2000. Estimation of metabolic protein requirement to cover unavoidable losses of endogenous nitrogen in maintenance of cattle. In: Owens, F.N. (eds.). Protein Requirements for Cattle. Oklahoma Agric. Exp. pp. 183-197.

Van Soest, P.J. and Robertson, J.B., 1985. Analysis of Forage and Fibrous Foods. A Laboratory Manual for Animal Science. 613 Cornell University, Ithaca, New York, USA.

Zemichael, G. 2007. Supplementation of sesame seed (Sesame indicum) cake, wheat bran and their mixtures on feed intake, digestibility, live weight changes and carcass characteristics of Tigray sheep fed a basal diet of tef straw. MSc Thesis, Haramaya University, Ethiopia. 